Nederlandse Taalkunde

www.nederlandsetaalkunde.nl

Uitgave: Amsterdam University Press

\title{
Sentence-medial if-clauses in Dutch
}

Frequency, semantic domain and syntactic integration ${ }^{1}$

\author{
Alex Reuneker
}

NT 22 (1): 137-148

DOI: 10.5117/NEDTAA2017.1.REUN

\begin{abstract}
Sentence-medial if-clauses deviate from regular clause-order patterns by their insertion into the main clause, rather than preceding or following it. This phenomenon is analysed in Dutch in terms of semantic domain and syntactic integration.
\end{abstract}

Keywords: conditionals, Dutch, clause order, syntactic integration

\section{$1 \quad$ Introduction}

Studies on conditionals often exclusively look at sentence-initial if-clauses. The order protasis-apodosis (i.e. 'if p, (then) q') has been declared the 'usual order' (Comrie 1986: 84), the 'default order' (Dancygier 1998: 149) and a language universal (Greenberg 1963: 84-5). Several studies however note the inverted pattern (i.e. 'q, if p'). For instance, Quirk, Greenbaum, Leech \& Svartvik (1985: 1089) include examples of sentence-final if-clauses, but they do not offer a further analysis. Declerck \& Reed (2001: 367, 397) argue that sentence-final if-clauses are 'syntactically marked', licensing pragmatic differences. A number of studies have indeed found such differences between sentence-initial and sentence-final if-clauses in language corpora (e.g. Ford \& Thompson 1986; Dancygier \& Sweetser 2005: 174-6; Carter-Thomas \& Rowley-Jolivet 2008). Sentence-medial position, as in (1), however, has largely been neglected.

1 I would like to thank Ronny Boogaart for valuable discussions and feedback and an anonymous reviewer for insightful comments and suggestions. 
(1) Tripoli stemt er mee in dat de verdachten, als ze schuldig worden bevonden, hun straf onder toezicht van de Verenigde Naties uitzitten in een Schotse cel. [Telegraaf, nie_siob]

Tripoli agrees that the suspects, if they are found guilty, undergo their punishment under the auspices of the United Nations in a Scottish cell.

Ford \& Thompson (1986: 356), for instance, explicitly exclude sentencemedial if-clauses: 'We excluded conditionals which appeared somewhere in the middle of the "consequent" clause.' Apart from some notable exceptions (Carter-Thomas \& Rowley-Jolivet 2008; Dancygier 1998), sentencemedial conditionals have not received much attention. This contribution addresses three questions concerning sentence-medial if-clauses in Dutch as compared to English.

First, if sentence-medial if-clauses are overlooked so often, is this reflected in actual language use by non-occurrence or low frequency? Second, Dancygier (1998: 106-107, 152-154) argues that sentence-medial ifclauses express metatextual functions. Given that she provides no corpus information regarding sentence-medial if-clauses, does the claim hold for actual language use data? The third question is how sentence-medial conditionals should be analysed syntactically with regard to their host, the main clause. These questions are taken up in the following sections respectively.

\section{$2 \quad$ Frequency of sentence-medial if-clauses}

The corpus used for this study is the section of Dutch newspaper articles from the CONDIV corpus (Deygers, Van Den Heede, Grondelaers, Speelman, \& Van Aken 2000). ${ }^{2}$ From this corpus, 500 subordinate if-clauses were randomly selected, of which 21 were disqualified because they did not introduce a condition. ${ }^{3}$ The position of the if-clauses was categorised manually. As Dancygier's work focuses on (American) English rather than

2 Examples are from this corpus, unless stated otherwise. References to exact sources are given between square brackets.

3 These clauses introduced, for instance, temporal, rather than conditional relations. In Dutch, als (if) is frequently used to express temporal relations, while in English such relations are usually expressed using when. 
on Dutch, a random sample of 200 sentences including if was extracted from the newspaper section of the Corpus of Contemporary American English (Davies 2008). ${ }^{4}$ The analyses yielded the following results.

Table 1 Distribution of clause position in conditionals $\left(x^{2}(d f=2, N=641)=55.732, p<0.01\right)$

\begin{tabular}{lllll}
\hline & Sent. initial (\%) & Sent. medial (\%) & Sent. final (\%) & Total \\
\hline Dutch & $130(27.1)$ & $31(6.5)$ & $318(66.4)$ & 479 \\
English & $96(59.3)$ & $9(5.6)$ & $57(35.2)$ & 162 \\
\hline
\end{tabular}

Looking at the Dutch data, the most frequent order is sentence-final $(66.4 \%)$, followed by sentence-initial $(27.1 \%)$. This is not the case for the English data, in which the frequencies of sentence-initial (59.3\%) and sentence-final $(35.2 \%)$ if-clauses are almost mirrored compared to Dutch. ${ }^{5}$ Nevertheless, the data for both languages deviate from what has been called the normal or default order for English (see section 1). This applies especially to Dutch, as the most frequent order is not protasis-apodosis (sentence-initial), but apodosis-protasis (sentence-final). More important for the current discussion is the similarity in frequencies of sentence-medial conditional clauses; both add up to around 6 percent of all conditional clauses.

A conditional was classified as sentence-medial when the if-clause occurred in the middle field, i.e. between the brackets or poles of the main clause (Haeseryn, Romijn, Geerts, De Rooij, \& Van den Toorn 1997: 1225). It must be noted however that the first pole, usually taken by the finite verb, like moet (must) in (2), can also be taken by a subordinate conjunction like dat (that) in (3).

(2) Hij moet als het aan de officier ligt voor anderhalf jaar de cel in.

[Telegraaf, nie_siod]

He must if it's up to the officer be sent to jail for one and a halfyears.

(3) Wie garandeert mij dat als je betaalt de dader ook wordt aangehouden? [Telegraaf, nie_s4]

Who guarantees me that if you pay the perpetrator will be arrested?

438 sentences in which the if-clause was insubordinate (i.e. used independently), part of 'as if or introduced a complement clause, as in 'He asked if he could come' (i.e. whether), were excluded.

5 While genre and mode are known to influence sentence order (Ford \& Thompson 1986; Ford 1997), for this research only newspaper texts were used. 
When dat in (3) is analysed as the first pole, the example should be classified as a sentence-medial conditional; i.e. the als-clause 'als je betaalt' ('if you pay') is inserted into the subordinate clause. It is however also possible to classify (3) as sentence-initial, as one could argue that the complete conditional is embedded in another clause and that the sentence-initial order is maintained within the embedded clause. ${ }^{6}$ While sentences of the type in (2) are uncontroversial cases of sentence-medial conditionals, sentences of the type in (3) were also classified as sentence-medial. The first reason for doing so is the regular SOV order in the dat-clause, as in (4), as opposed to subject-verb inversion typical in main clauses of non-embedded sentence-initial conditionals, as in (4a). Consequently, deletion of the als-clause in (4) renders a grammatical result, as in (4b), whereas deletion of the matrix clause would not. This syntactic independence, comparable to that of parentheticals, is typical for sentence-medial conditionals (see section 4).

(4) Het eerste ziektejaar is zo verregaand geprivatiseerd dat, als het fout gaat, pas na een jaar duidelijk wordt hoe het zit. [NRC, variag] The first year of illness is privatized to such an extent that, if it goes wrong, the situation will only become clear after a year.

(4a) Als het fout gaat, wordt pas na een jaar duidelijk hoe het zit. If it goes wrong, the situation will only become clear after a year.

(4b) Het eerste ziektejaar is zo verregaand geprivatiseerd dat pas na een jaar duidelijk wordt hoe het zit.

The first year of illness is privatized to such an extent that the situation will only become clear after a year.

Second, the intonation pattern of an embedded conditional resembles that of the 'standard' type in (2); als is stressed and there is a intonation break before and after the conditional clause, after which the intonation pattern of the matrix clause is continued. Data from the Corpus of Spoken Dutch (Oostdijk 2000) reveal that, after the als-clause, the speaker often resumes the embedded clause by repeating the subordinating conjunction dat, as in (5).

6 This view was suggested by an anonymous reviewer. For Dutch sentence-medial conditionals, 10 occurrences $(32.3 \%)$ were embedded, while 21 occurrences $(67.7 \%)$ were non-embedded. The pattern within the embedded clause was sentence-initial 7 times, as in (4), and sentence-medial 3 times, as in (1). In the English data, 3 conditionals (33.3\%) were embedded (2 with that and 1 without an explicit conjunction), 6 were non-embedded (66.7\%). The embedded pattern was sentence-initial 2 times, as in (9), and sentence-medial once, as in (10). 
(5) $[\ldots]$ u weet ook dat als je iets koelt dat dat je uh uh dat je warmte onttrekt $[. .].[\mathrm{CGN}$, fnoooo77) $[\ldots]$ you also know that if you cool something that you extract heat $[\ldots]$

These observations show that, when the complex sentence as a whole is taken into account, if-clauses following that should be interpreted as 'standard' sentence-medial conditionals.

Sentence-medial conditionals thus deviate from regular clause-order patterns by the insertion of the protasis (subordinate clause) into the apodosis (main clause) and while their frequency is low, the results indicate that they are less of an anomaly than their virtual absence from the literature suggests.

\section{Domains of sentence-medial if-clauses}

Dancygier suggests that sentence-medial if-clauses predominantly occur in the metatextual domain. To test this hypothesis, all Dutch and English conditionals were categorised into Sweetser's (1990) \& Dancygier's (1998) domains of causal and conditional relations. ${ }^{7}$

Sweetser's framework defines three domains of causal relations in (amongst others) conditional conjunctions. In content conditionals the fulfilment of the protasis causes or enables the realisation of the situation in the apodosis (e.g. 'If Mary goes, John will go.' Sweetser 1990: 114), while in epistemic conditionals knowledge of the truth of the protasis causes or enables the conclusion expressed in the apodosis ('If she's divorced, (then) she's been married.' 1990: 116). In speech-act conditionals the fulfilment of the state described in the protasis is a condition for the performance of the speech act in the apodosis (e.g. 'If it's not rude to ask, what made you decide to leave IBM?' 1990: 118). Dancygier (1998: 106) adds metatextual relations, in which the protasis comments on the appropriateness of the linguistic form of the apodosis (e.g. 'My husband, if I can still

7 It is important to note that several problems arise when applying these classifications to actual language data. For instance, 20 conditionals had an interrogative main clause, as in 'En als je kust, welke vrouwelijke collega's kus je wel en welke niet?' ('And if you kiss, which female colleagues do you kiss and which don't you?'). Van der Auwera (1986) regards these conditionals as causal conditionals, Sweetser (1990: 120-121) analyses them as speech-act conditionals, while Dancygier (1998: 89, 126-130) analyses them as 'contextually bound questions'. Here, Sweetser (1990) was followed. 
call him that, hates onion soup.'). The categorisation results for Dutch conditionals are presented in table 2.

Table 2 Distribution of position and domain in Dutch conditionals (Fisher's Exact Test, $\mathrm{p}<0.01$, two-sided)

\begin{tabular}{llllll}
\hline \multicolumn{5}{c}{ Domain } \\
\hline & Cont. (\%) & Epist. (\%) & Speech-act (\%) & Meta. (\%) & Total \\
\hline Sent. initial & $116(89.2)$ & $10(7.7)$ & $4(3.1)$ & $0(0.0)$ & 130 \\
Sent. medial & $26(83.9)$ & $0(0.0)$ & $1(3.2)$ & $4(12.9)$ & 31 \\
Sent. final & $289(90.9)$ & $4(1.3)$ & $24(7.5)$ & $1(0.3)$ & 318 \\
Total & $431(90.0)$ & $14(2.9)$ & $29(6.1)$ & $5(1.0)$ & 479 \\
\hline
\end{tabular}

Examples of sentence-medial als-clauses from the Dutch corpus in the given domains are given in (6-8) below.

(6) Die bescherming valt - als de voorstellen van de Commissie werkelijkheid worden - weg indien een virtuele boekhandelaar vanuit Londen boeken met forse kortingen naar Nederland gaat versturen. [NRC, nieuws7] (content domain) That protection is - if the Commission's proposals become reality - lost in case a virtual bookseller from London ships books to the Netherlands with large discounts.

(7) Automobilisten die geen oprit hebben, kunnen, als ze toch hun auto vanaf de weg willen verkopen, een verzoek bij de gemeente indienen. [De Limburger, nieuwso2] (speech-act domain)

Motorists who do not have a driveway, can, if they still want to sell their cars from the street, submit a request to the municipality.

(8) $\mathrm{Nu}$ is het beeld, als u wilt: het vijandbeeld, veel diffuser geworden en de Amerikaanse bereidheid in te grijpen navenant onzekerder. [NRC, varia5] (metatextual domain)

Now the image is, if you like: the image of the enemy, much more diffuse and the American willingness to act accordingly is more uncertain.

Sentence-medial conditionals are found mostly in the content domain, but this domain is most frequent in any position. There are no occurrences in the epistemic domain and only one in the speech-act domain. Given the overall low frequencies of the latter two domains, this is what can be expected. There is however a significantly higher frequency of metatextual relations presented in sentence-medial position than in other positions, meaning that metatextual conditionals are expressed in medial position 
more often than in other positions. ${ }^{8}$ Table 2 thus suggests that sentencemedial if-clauses in Dutch, like if-clauses in other positions, are used most frequently to express content relations, but when the perspective is shifted from position to function, it becomes clear that almost all metatextual relations, referring to the appropriateness of the linguistic form of the apodosis, are expressed in sentence-medial position.

The distribution of English sentence-medial if-clauses is given below.

Table 3 Distribution of position and domain in English conditionals (Fisher's Exact Test, $\mathrm{p}<0.01$, two-sided)

\begin{tabular}{llllll}
\hline & \multicolumn{5}{c}{ Domain } \\
\hline & Cont. (\%) & Epist. (\%) & Speech-act (\%) & Meta. (\%) & Total \\
\hline Sent. initial & $80(83.4)$ & $7(7.3)$ & $9(9.4)$ & $0(0.0)$ & 96 \\
Sent. medial & $3(33.3)$ & $0(0.0)$ & $0(0.0)$ & $6(66.7)$ & 9 \\
Sent. final & $50(87.7)$ & $3(5.3)$ & $2(3.5)$ & $2(3.5)$ & 57 \\
Total & $133(82.1)$ & $10(6.2)$ & $11(6.8)$ & $8(4.9)$ & 162 \\
\hline
\end{tabular}

The number of sentence-medial if-clauses found in the epistemic domain and in the speech-act domain resemble the Dutch results. However, the distribution over the content and metatextual domains, as in (9) and (10) respectively, is different.

(9) Even Republicans warn that, if the problem defies solution, Bush will get blamed. [USA Today, 2001] (content domain)

(10) Provincial officials say that election teams rarely, if ever, ventured outside district capitals. [CS Monitor, 2008] (metatextual domain)

English sentence-medial conditionals are found mostly in the metatextual domain, which corresponds to Dancygier's observation that they 'frequently take a position as close as possible to the "text" commented on which may mean a position within the main clause rather than preceding or following it' (1998: 152). Contrary to Dutch, in which sentence-medial ifclauses show a preference for metatextual conditionals only relative to the high overall frequency of content conditionals, sentence-medial if-clauses in English seem to show an absolute preference for metatextual conditionals. This means that, contrary to Dutch, almost all sentence-medial conditionals express metalinguistic relations and, similar to Dutch, almost all metalinguistic relations are express in sentence-medial position. Pre-

8 Fisher's Exact Test was used because of low frequency occurrences and null counts. 
cautions must be taken in interpreting these data, because the percentages may suggest more robust findings than the low frequencies allow. Furthermore, in four of the six cases the if-clause is a formulaic, elliptical expression - either 'if any' or 'if ever' (cf. Dancygier 1998: 145), which, together with 'if anything', does not function as an antecedent to a consequent anymore, but as a 'small afterthought' referring to presuppositions (Athanasiadou \& Dirven 2000: 20-21). ${ }^{9}$ This point will be elaborated in the next section.

\section{Syntactic integration of sentence-medial if-clauses}

Renmans \& Van Belle's (2003) syntactic analysis of (sentence-initial) conditionals in terms of Sweetser's (1990) domains shows that if-clauses in content conditionals, as in (11), are syntactically integrated the most (cf. König \& Van der Auwera 1988), compared to epistemic and speech-act conditionals, illustrated in (12) and (13) respectively.

(11) Als het morgen regent, blijven we thuis. (Renmans \& Van Belle 2003: 142; integrated, i.e. inversion in main clause)

If it rains tomorrow, we will stay at home.

(12) Als hij het weet, dan moet er een lek zijn geweest. (Renmans \& Van Belle 2003: 144; resumptive, i.e. inversion and particle dan) If he knows, then there must have been a leak.

(13) Als je dorst hebt, er is limonade in de koelkast. (Renmans \& Van Belle 2003: 142; non-integrated, i.e. main clause order in both clauses)

If you are thirsty, there is lemonade in the refrigerator.

Despite their frequency in the content domain, none of the sentence-medial conditionals found in the Dutch corpus show any degree of syntactic integration. A number of analyses is possible, of which two are discussed here.

First, with respect to their degree of syntactic integration, sentencemedial conditionals resemble afterthoughts, or what Declerck \& Reed call 'postscript-P conditionals'.

9 There are no elliptical equivalents for 'if any' and 'if ever' in Dutch, which could explain their difference in distribution. 
(14) I'll drop in and see you at 10 tonight, if you will be alone. (Declerck \& Reed 2001: 367)

(15) Which of these cars is more comfortable - if you had to make a choice? (Declerck \& Reed 2001: 367)

In (14) the relation between the protasis and apodosis exists in the content domain and as such it is a 'restrictive postscript: it restricts the validity of Q a posteriori' (Declerck \& Reed 2001: 367 ). In (15) this is not the case, as the relation between protasis and apodosis exists in the speech-act domain and is non-restrictive. The similarity between (14), (15) and sentence medial-if is that the postscripts do not show any syntactic integration and can be omitted without affecting the main clause. Their non-integration does however not imply that they are necessarily metatextual; sentence-medial if-clauses involve a postscript-type comment, but not necessarily on the metatextual level.

Second, sentence-medial if-clauses show a resemblance to parentheticals like (16), as they both occur in medial position of a sentence. ${ }^{10}{ }^{11}$

(16) When we got home, I told her, we would have to have the locks changed. (Huddleston \& Pullum 2002: 1024)

Huddleston \& Pullum (2002: 1024) argue that parentheticals do 'not belong in a matrix clause', but are a kind of supplement. A parenthetical is 'a structural element which has no obvious grammatical link with the clause to which it pertains' (Nuyts 2001: 117) and, as argued for in section 2, is 'preceded and followed by an intonation break' (Broekhuis \& Corver 2015: 662). Huddleston \& Pullum (2002: 1748) present the enclosed element 'as inessential material that can be omitted without affecting the well-formedness and without any serious loss of information'. This fits in with Athanasiadou \& Dirven's (2000: 17-22) analysis of a set of parenthetical constructions as 'metacommunicative conditionals'. They identify three

10 A small number of studies have commented on parenthetical conditionals. Haiman (1986: 216) argues parenthetical conditionals as 'Greetings from your affectionate, if absent-minded, son.' to be 'invariably concessive', as does König (1986: 239), but this is not corroborated by our data.

11 In terms of Schelfhout, Coppen and Oostdijk (2003), sentence-medial conditionals could be analysed as 'free intercalations' - parentheticals with a form independent of the host that occur before, in and after the main clause. The question is however whether the parameter 'independent form' is a suitable parameter for analysing inherently subordinate if-clauses. 
uses of these conditionals: metapragmatic, metalinguistic and restrictive, as in (17-19) respectively.

(17) Good gracious me, sir, if I may make so bold - it's a bit shocking, isn't it? (Athanasiadou \& Dirven 200: 18)

(18) I've come to offer my congratulations, if that's the right word. (Athanasiadou \& Dirven 2000: 19)

(19) This is a time - if there ever was one - for parents to show their thoughtfulness and generosity towards each other. (Athanasiadou \& Dirven 2000: 20)

The metapragmatic parenthetical conditional in (17) addresses the appropriateness of the speech act it is inserted in. In (18), the metalinguistic conditional does not address the speech act as a whole, but (parts of) its linguistic form. In (19), the restrictive conditional addresses the presupposition connected to the situation expressed - 'This is a time' presupposes the existence of such a time. All uses distinguished by Athanasiadou \& Dirven are 'metacommunicative' and as such adhere to Huddleston \& Pullum's characterisation of parentheticals as extraneous material. The corpus data however show that this is not the case for all sentence-medial conditionals. For example, the original utterance in (2) seems to have the illocution of ascribing a view to the officer. There is therefore certainly a 'serious loss of information' (i.e. the explicit perspective of the officer) in omitting the conditional clause, as in (2a).

(2) Hij moet als het aan de officier ligt voor anderhalf jaar de cel in. He must if it's up to the officer be sent to jail for one and a halfyears.

(2a) Hij moet voor anderhalf jaar de cel in. He must be sent to jail for one and a halfyears.

This is not surprising, as the parentheticals analysed by Athanasiadou \& Dirven reside in the metacommunicative domain, while this is not necessarily the case for all sentence-medial conditionals.

\section{Conclusions}

From this contribution, it becomes clear that sentence-medial if-clauses are less frequent than sentence-initial and sentence-final if-clauses and that they differ significantly from the other orders with respect to condi- 
tional domains and syntactic integration. They should therefore not be neglected in research on conditionals. Dancygier's (1998) observation that sentence-medial if functions in the metatextual domain was nuanced for Dutch by the high percentage of content-domain relations found, which do not show the degree of syntactic integration that may be expected based on Renmans \& Van Belle's (2003) analysis. In this regard, sentence-medial if-clauses behave like parentheticals, but they do not present material that is semantically extraneous to the host.

\section{References}

Athanasiadou, A. \& R. Dirven (200o). Pragmatic conditionals. In: A. Foolen \& F. Van Der Leek (eds.), Constructions in cognitive linguistics. Amsterdam: John Benjamins, 1-26.

Broekhuis, H. \& N. Corver (2015). Syntax of Dutch: Verb and verb phrases, Volume 2. Amsterdam: Amsterdam University Press.

Carter-Thomas, S. \& E. Rowley-Jolivet (2008). If-conditionals in medical discourse: From theory to disciplinary practice. Journal of English for Academic Purposes 7(3), 191-205.

Comrie, B. (1986). Conditionals: A typology. In: E. Traugott, A. Meulen, J. Reilly \& C. Ferguson (eds.), On Conditionals. Cambridge: Cambridge University Press, 77-99.

Dancygier, B. (1998). Conditionals and prediction: time, knowledge, and causation in conditional constructions. Cambridge: Cambridge University Press.

Davies, M. (2008). The corpus of contemporary American English: 450 million words, 1990-present. <http://corpus.byu.edu/coca/>

Dancygier, B. \& Sweetser, E. (2005). Mental Spaces in Grammar: conditional constructions. Cambridge: Cambridge University Press.

Declerck, R. \& S. Reed (2001). Conditionals: a comprehensive empirical analysis. Berlin: Walter de Gruyter.

Deygers, K., V. Van Den Heede, S. Grondelaers, D. Speelman \& H. Van Aken (2000). Het CONDIVcorpus geschreven Nederlands. Nederlandse Taalkunde 5(4), 356-363.

Ford, C.E. (1997). Speaking conditionally: Some contexts for if-clauses in conversation. In: A. Athanasiadou \& R. Dirven (eds.), On conditionals again. Amsterdam: John Benjamins, 387413 .

Ford, C.E. \& S.A. Thompson (1986). Conditionals in discourse: a text-based study from English. In: E.C. Traugott, A. Ter Meulen, J. Snitzer Reilly \& C. A. Ferguson (eds.), 353-372.

Greenberg, J.H. (1963). Some Universals of Grammar with Particular Reference to the Order of Meaningful Elements. In: J.H. Greenberg (Ed.), Universals of Human Language. Cambridge: MIT Press, 73-113.

Haeseryn, W., K. Romijn, G. Geerts, J. De Rooij \& M. van Den Toorn (eds.) (1997). Algemene Nederlandse Spraakkunst (2nd ed.). Groningen: Martinus Nijhoff.

Haiman, J. (1986). Constraints on the form and meaning of the protasis. In: E.C. Traugott, A. Ter Meulen, J. Snitzer Reilly, \& C.A. Ferguson (eds.), 215-227.

Huddleston, R.D. \& G.K. Pullum (2002). The Cambridge grammar of the English language. Cambridge: Cambridge University Press.

König, E. (1986). Conditionals, concessive conditionals and concessives: areas of contrast, overlap 
and neutralization. In: E.C. Traugott, A. Ter Meulen, J. Snitzer Reilly, \& C.A. Ferguson (eds.), $215^{-227}$.

König, E. \& J. Van der Auwera (1988). Clause integration in German and Dutch conditionals, concessive conditionals, and concessives. In: J. Haiman \& S.A. Thompson (eds.), Clause combining in grammar and discourse. Amsterdam: John Benjamins, 101-134.

Nuyts, J. (2001). Epistemic modality, language, and conceptualization: A cognitive-pragmatic perspective. Amsterdam: John Benjamins.

Oostdijk, N. (2000). Het Corpus Gesproken Nederlands. Nederlandse Taalkunde 5(3), 280-284.

Quirk, R., S. Greenbaum, G. Leech \& J. Svartvik (1985). A Comprehensive Grammar of the English Language. London: Longman.

Renmans, B. \& W. Van Belle (2003). The use of the particle dan in Dutch conditional sentences. Leuvense Bijdragen - Leuven Contributions in Linguistics and Philology 92(1), 141-158.

Schelfhout, C., P.A. Coppen \& N. Oostdijk (2003). Intercalaties? Dat zijn geloof ik van die tussendingen. Gramma/TTT 10(1), 27-44.

Sweetser, E.E. (1990). From etymology to pragmatics: metaphorical and cultural aspects of semantic structure. Cambridge: Cambridge University Press.

Van der Auwera, J. (1986). Conditionals and speech acts. In: E.C. Traugott, A. Ter Meulen, J. Snitzer Reilly, \& C.A. Ferguson (eds.), 197-214.

\section{About the author}

Alex Reuneker, Leiden University Centre for Linguistics, Leiden University E-mail: a.reuneker@hum.leidenuniv.nl 